Семенда Дмитро Костянтинович кандидат економічних наук, професор, професор кафедри підприємництва, торгівлі та біржової діяльності, заслужений працівник сільського господарства України, Уманський національний університет садівництва, вул. Інститутська, 1, м. Умань, 20300, тел.: (04744) 3-87-89, https://orcid.org/0000-0003-2714-0436

Семенда Ольга Володимирівна кандидат економічних наук, доцент, старший викладач кафедри маркетингу, Уманський національний університет садівництва, вул. Інститутська, 1, м. Умань, 20300, тел.: (04744) 3-18-24, https://orcid.org/0000-0002-6690-645X

\title{
РОЛЬ ДЕРЖАВИ У РОЗВИТКУ ПІДПРИЕМНИЦТВА В УКРАЇНІ
}

Анотація. Протягом останніх років Україна переживала гострі політичні, безпекові та економічні виклики. Після повстання на «Майдані» в лютому 2014 року країна стала свідком кількох визначних подій, зокрема розгортання конфлікту на сході України. 32014 по 2019 рік Уряд провів ключові реформи, зокрема: проведення значної фіскальної консолідації, перехід до гнучкого обмінного курсу, реформування тарифів на енергоносії та соціальної допомоги, підвищення прозорості державних закупівель, спрощення регулювання бізнесу, стабілізацію та реструктуризацію банківського сектору, просування вперед реформи охорони здоров'я та пенсійного забезпечення та створення антикорупційних агенцій. У той же час українці продовжують відчувати, що для покращення державного управління необхідно зробити більше.

В умовах реформування економіки державне регулювання підприємництва та підприємницької діяльності набуває дедалі більшої актуалізації. Саме від того як держава впливатиме на підприємництво та підприємницьку діяльність за допомогою різних методів, інструментів, залежатиме розвиток економіки країни, іiї висока конкурентоспроможність на внутрішньому та зовнішньому ринках.

В статті розглянуто роль держави, iї вплив на розвиток підприємств в Україні. Обгрунтовано, що роль держави в діяльності підприємств, з огляду на те, що глобалізація вносить у систему співвідношення держави і ринку нові елементи, не зменшується, а радше збільшується за рахунок глобалізації економіки. Виникає потреба зміни моделі економічного розвитку факторів інноваційного зростання, значного збільшення інвестиційної активності, забезпечення нової якості розвитку економіки та як наслідок розвитку ефективного та більш вільного підприємництва. Провідна роль у формуванні 
підприємницького середовища на всіх рівнях належить державі, яка розробляє економічну стратегію та політику, створює законодавчу базу, створює умови та механізми для реалізації конкурентних переваг національних виробників на внутрішньому та світовому ринках.

Формування та розвиток сприятливого підприємницького середовища залежить від багатьох факторів. Однак із усього різноманіття цих факторів найважливішу роль у створенні сприятливого підприємницького середовища грає доброзичливо налаштоване політичне середовище, стабільність інститутів економічної та політичної влади.

Ключові слова: держава, ринок, глобалізація, трансформація, економічні інтереси.

Semenda Dmytro Kostiantynovych Candidate of Economic Sciences, Professor, Professor of the Department of Entrepreneurship, Trade and Exchange Activities, Honored Worker of Agriculture of Ukraine, Uman National University of Horticulture, 1, Institutska St., Uman, 20300, tel .: (04744) 3- 87-89, https://orcid.org/0000-0003-2714-0436

Semenda Olha Volodymyrivna Candidate of Economic Sciences, Associate Professor, Senior Lecturer, Department of Marketing, Uman National University of Horticulture, 1, Institutska St., Uman, 20300, tel .: (04744) 3-18-24, https://orcid.org/0000-0002-6690-645X

\section{THE ROLE OF THE STATE IN THE DEVELOPMENT OF ENTREPRENEURSHIP IN UKRAINE}

Abstract. In recent years, Ukraine has experienced acute political, security and economic challenges. After the uprising on the Maidan in February 2014, the country witnessed several significant events, including the unfolding of the conflict in eastern Ukraine. From 2014 to 2019, the Government carried out key reforms, including: significant fiscal consolidation, transition to a flexible exchange rate, reform of energy tariffs and social assistance, increasing transparency in public procurement, simplifying business regulation, stabilizing and restructuring the banking sector, advancing security reforms health and pensions and the creation of anti-corruption agencies. At the same time, Ukrainians continue to feel that more needs to be done to improve public administration.

In the context of economic reform, state regulation of entrepreneurship and entrepreneurial activity is becoming increasingly important. The development of the country's economy and its high competitiveness in domestic and foreign markets will depend on how the state will influence entrepreneurship and entrepreneurial activity with the help of various methods and tools.

The article considers the role of the state, its impact on the development of enterprises in Ukraine. It is substantiated that the role of the state in the activities of 
enterprises, given that globalization introduces new elements into the system of statemarket relations, does not decrease, but rather increases due to the globalization of the economy. There is a need to change the model of economic development of factors of innovative growth, a significant increase in investment activity, ensuring a new quality of economic development and as a consequence of effective and freer entrepreneurship. The leading role in shaping the business environment at all levels belongs to the state, which develops economic strategy and policy, creates the legal framework, creates conditions and mechanisms for realizing the competitive advantages of domestic producers in domestic and global markets.

The formation and development of a favorable business environment depends on many factors. However, of all the variety of these factors, the most important role in creating a favorable business environment is played by a friendly political environment, the stability of institutions of economic and political power.

Keywords: state, market, globalization, transformation, economic interests.

Постановка проблеми. Роль держави у стимулюванні та регулюванні підприємництва є важливою для будь-якої країни. Держави завжди активно втручаються в діяльність підприємців, виступаючи спостерігачем або арбітром. При цьому використовується досить різноманітний інструментарій, що включає широкий набір економічних і адміністративних важелів.

Найбільшу цінність для підприємництва представляють функції держави як прискорювача підприємницького процесу. У зв'язку з чим доцільно їх розглянути детальніше.

Аналіз останніх досліджень і публікацій. Питаннями державного регулювання підприємництва, і зокрема в Україні, досить активно займаються такі вчені, як О.Амоші, Ю.Бажала, А.Бутенко, Б.Гаврилишин, З.Варналій, П.Круш, І.Кузнєцов, В.Литвиненко, І.Малий, В.Мельник, С.Мочерний, Н.Савчук. В.Сизоненко, Т.Ткаченко, Д.Чеберкус, М.Чумаченко та інші. Вчені розглядають теоретичні та практичні аспекти регулювання економіки, вивчають світовий досвід державного регулювання бізнесу. Разом із тим, чимало теоретичних i практичних питань проблематики залишаються не достатньо дослідженими 3 точки зору комплексності та системності. Залишається низка питань, які потребують подальшого дослідження державного регулювання підприємницької діяльності в Україні.

Мета статті - проаналізувати розвиток підходів до визначення ролі держави в економіці та ступеня ii втручання в ринкові процеси, з'ясувати економічні функції сучасної держави в умовах глобалізації.

Виклад основного матеріалу. Обрання шляху мінімізації ролі держави від початку незалежності України можна пояснити певною втомою від централізованої регламентації радянського минулого. Проте досить важко пояснити, чому протягом 30 років роль та місце держави не коригувалися відповідно до тенденцій розвитку країн світу. Як підкреслював видатний 
американський економіст Дж.К. Гелбрейт ще на початку 1990-х років, «капіталізм не міг би вижити у своїй початковій або чистій формі. Але під натиском він зміг пристосуватися» [1]. Повною мірою це стосується й поточної ролі держави в економічному розвитку країн світу.

Процеси переосмислення ролі держави відбуваються у світі досить активно. Можна послатися на історію економічної думки і визначити ті чи інші теоретичні підходи та практичні реалізації ролі держави в різних країнах світу. Можна також наводити досвід багатьох країн від Франції до Південної Кореї, від Італії до США, де роль держави в соціальному та економічному житті $\epsilon$ набагато вагомішою, ніж в Україні, не кажучи вже про так звану «скандинавську модель», яка традиційно $є$ взірцем вагомості і державних впливів, і соціальності серед розвинутих економік. У будь-якому випадку роль $і$ місце держави в умовах України треба не лише переглянути, а й спрямовано посилити.

Досліджуючи питання розвитку світової економіки і місця України в цьому процесі, необхідно також ураховувати поточний стан та інші глобальні проблеми. Особливої значущості це набуває в контексті проблематики пандемії COVID-19 і відповідних негативних впливів на макроекономічні показники.

За даними Global Economic Prospects Світового банку, станом на червень 2021 р. прогноз зростання світової економіки на 2021 р. поліпшився 3 4,1 до $5,6 \%$, проте для країн, що розвиваються, знизився до 2,9\%. Попри розрив між економіками розвинутих країн і тими, що розвиваються, світовий ВВП у поточному році зросте найбільше за 80 років - на 5,6\%. Це відбудеться переважно завдяки зростанню економік США і Китаю, які мають збільшитися, відповідно, на 6,8 і 8,5\%. Для України цей прогноз демонструє покращення у 2022-2023 рр. Так, у 2021 р. очікується зростання на 3,8\%, у наступні два роки на 3,1\% (раніше очікувалося 3\%) [2].

Світовий досвід демонструє різноманітні моделі державного впливу на соціально-економічний розвиток. Традиційно можна навести приклад США, де підтримується ринкова система, але втручання держави $\epsilon$ відчутним регулятивним чинником. У розвинутих країнах Західної Європи держава відіграє головну роль у розподілі прибутків за допомогою програм соціального фінансування. Останнє може характеризуватись як соціально-ринкова модель розвитку.

Світовий досвід ролі держави в сучасних умовах передбачає необхідність іiі оптимізації в Україні. Під оптимізацією розуміються зміни ролі держави відповідно до світових тенденцій і рівня розвитку національної економіки. У даному випадку процес вибору найкращого варіанта рішень 3 багатьох можливих стосується саме ролі держави в соціально-економічному розвитку. При цьому роль держави якісно відрізняється на етапах становлення, формування ринкової економіки і в умовах функціонування економіки, що вже склалася, відрегульованої економіки ринкового типу. У свою чергу оптимізація 
ролі держави в умовах України повинна грунтуватись як на внутрішньому, так $\mathrm{i}$ на зовнішньому напрямах. Якщо внутрішній розвиток передбачає виконання конституційних положень, то зовнішній - виступає як орієнтир для України в плані подальшого геоекономічного і геополітичного розвитку.

Обговорення проблем трансформації функцій держави в умовах глобалізації має важливе як теоретичне, так i практичне значення. Це обумовлено тим, що сучасні соціально-економічні трансформації глобального характеру суттєво змінюють місце і роль держави в житті кожної людини, країни і суспільства в глобальному вимірі. Глобалізація приводить до того, що, 3 одного боку, частина соціально-економічних процесів усередині країн виходить з-під впливу національної держави, а 3 іншого приватні міжнаціональні структури починають значною мірою визначати перебіг подій у тій чи іншій державі. Виникає суперечність між інтересами транснаціональних і міжнаціональних структур та політико-економічними інтересами держави [3]. Держава, по-перше, виражає загальні економічні інтереси суспільства, подруге, представляє ці інтереси функцій у відношенні до кожного окремого господарюючого суб'єкта чи громадянина i в цій ролі виступає єдиним суб'єктом і монополістом [4].

В умовах глобалізації суттєве значення має розмежування внутрішніх i зовнішніх економічних функцій держави. Внутрішні функції держава виконує як агент суспільства у відношенні до національних суб'єктів господарювання i своїх громадян, а зовнішні у відношенні до інших держав та їх суб'єктів господарювання і громадян. Зовнішні функції держави завжди є похідними. Наприклад, розвиток зовнішньоекономічних відносин $є$ реалізацією такої основної функції держави, як вираження і представлення економічних інтересів суспільства, у зовнішніх відносинах.

Глобалізація вносить зміни в співвідношення внутрішніх i зовнішніх функцій. Відкритість економіки, рух капіталу, міграція робочої сили характеризують зовнішні відносини, які одночасно змінюють внутрішні умови функціонування економіки. Це, безумовно, необхідно враховувати в реалізації функцій держави шляхом здійснення адекватної соціально-економічної політики. Неналежне виконання державою своїх основних економічних функцій призвело до деіндустріалізації української економіки і перетворення іiі значною мірою на сировинний придаток більш розвинутих держав. В умовах суттєво нижчої від західних країн продуктивності праці та вищої ресурсомісткості виробництва практичне відкриття кордонів створило для іноземних суб'єктів господарювання вагомі конкурентні переваги, а для національних виробників - невигідні умови, що має своїм наслідком фрагментацію економіки і структурну деградацію.

Безперспективність тієї пасивної позиції, яку Україна зайняла щодо розбудови власного промислового виробництва, та хибність нині домінуючого підходу до розвитку вітчизняної економіки лише на основі використання 
поточних конкурентних переваг країни - дешевих природних, земельних i трудових ресурсів. Саме така позиція чималою мірою зумовила глибоку деіндустріалізацію, аграрізацію і посилення сировинного ухилу економіки України, тоді як для сталого розвитку необхідними $\epsilon$ формування перспективних конкурентних переваг, заснованих на інноваціях i високих технологіях, а зрештою - інклюзивна індустріалізація [5, с. 21-23].

Завданням держави має бути створення рівних конкурентних умов для національних і зарубіжних суб'єктів господарської діяльності на внутрішньому ринку України. Для цього потрібно вести відповідну митно-тарифну політику, враховуючи інтереси національних об'єднань виробників, завдання забезпечення цілісності господарського комплексу, необхідність підтримки експорту тощо. Замість цього було проведено необгрунтовану лібералізацію митно-тарифної політики.

Відповідно до законів архітектоніки, розрив у показниках рівнів розвитку, продуктивності праці, конкурентоспроможності, що перевищує 15\%, створює загрози для стабільності й може вести до дивергенції замість конвергенції, що відбувається значною мірою у відносинах України і Свропейського Союзу. Зважаючи на це, необхідним є коригування взаємовідносин України та ЄС 3 огляду на реальну ситуацію і тенденції розвитку. Водночас певних змін потребує й вітчизняна державна політика, яка має знайти адекватні відповіді на найбільш серйозні виклики європейської інтеграції нашої країни, що пов'язані 3 проблемами ऑiі інституційного розвитку та економічного зростання, деіндустріалізації, структурно-динамічних диспропорцій у зовнішній торгівлі, макрофінансової стійкості, а також гальмування макроекономічної конвергенції та поглиблення соціальної дивергенції «Україна-СС» [6, с. 11].

Відповідне коригування підходів вітчизняного державного регулювання має враховувати сучасну практику і досвід Євросоюзу щодо стратегічного, програмного, тактичного реагування за допомогою інструментів державної політики на виклики глобалізації, цифровізації, демографічних і соціальних трансформацій [7].

Негативна динаміка результативності функціонування аграрного сектору економіки України (табл. 1) на макрорівні протягом останніх років не може бути випадковою. Це насамперед наслідок незадовільного державного регулювання ринкових процесів. Такі загрозливі тенденції, безумовно, повинні спонукати державу удосконалювати систему державного управління аграрним сектором. Глобальне середовище, ринкова економіка, як і природа, з якою тісно пов'язана агропромислова діяльність, не пробачають помилок, неправильних або спрощених заходів регулювання відповідними процесами [8].

На сьогодні розбудова досконалої системи державного управління розвитком аграрного сектору економіки та сільських територій в Україні, включаючи удосконалення механізмів державно-приватного партнерства та самоврядування, виступає своєрідним мистецтвом, яким повинні займатися 
професійно і відповідально передусім кадри центрального органу виконавчої влади 3 питань аграрної політики в інтересах суспільства. Водночас у складній ситуації, в якій опинилася аграрна сфера держави, потрібно знайти «золоту середину» між зарегульованістю i дерегуляцією, забезпечити скасування штучних перепон, що, безумовно, дозволить реально підвищити конкурентоспроможність учасників вітчизняного аграрного ринку [9].

Таблицяя 1.

Показники результативності політики держави в аграрному секторі економіки України

\begin{tabular}{|c|c|c|c|c|c|c|c|}
\hline \multirow[b]{2}{*}{ Показник } & \multirow{2}{*}{$\begin{array}{l}\text { Одиниця } \\
\text { виміру }\end{array}$} & \multicolumn{5}{|c|}{ Рік } & \multirow{2}{*}{$\begin{array}{c}2019 \mathrm{p} . \\
\text { до } \\
2015 \mathrm{p}, \% \\
\end{array}$} \\
\hline & & 2015 & 2016 & 2017 & 2018 & 2019 & \\
\hline $\begin{array}{l}\text { Рівень } \\
\text { сільськогосподарських } \\
\text { підприємств (усі види діяльності) }\end{array}$ & $\%$ & 30,4 & 25,6 & 16,5 & 14,2 & 16,1 & 53,0 \\
\hline $\begin{array}{l}\text { Калорійність середньодобового } \\
\text { споживання населенням продуктів } \\
\text { харчування }\end{array}$ & ккал & 2799 & 2742 & 2707 & 2706 & 2691 & 96,1 \\
\hline 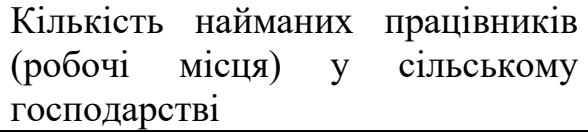 & тис. осіб & 500,9 & 513,2 & 489,2 & 479,8 & 461,5 & 92,1 \\
\hline $\begin{array}{l}\text { Валова додана вартість у цілому } \\
\text { по державі }\end{array}$ & млрд. грн. & 1689,4 & 2023,2 & 2519,6 & 3018,2 & 3418,1 & 202,3 \\
\hline $\begin{array}{l}\text { у т.ч. сільське, лісове і рибне } \\
\text { господарство }\end{array}$ & млрд. грн. & 239,8 & 279,7 & 304,0 & 361,2 & 358,1 & 143,9 \\
\hline $\begin{array}{l}\text { Капітальні інвестиції в цілому по } \\
\text { державі }\end{array}$ & млрд. грн. & 273,1 & 359,2 & 448,5 & 578,7 & 624,0 & 228,5 \\
\hline $\begin{array}{l}\text { у т.ч. сільське, лісове і рибне } \\
\text { господарство }\end{array}$ & млрд. грн. & 30,2 & 50,5 & 64,2 & 66,1 & 58,4 & 193,4 \\
\hline $\begin{array}{l}\text { Виробництво продукції сільського } \\
\text { господарства у у порівняльних } \\
\text { цінах 2016р. }\end{array}$ & млрд. грн. & 596,8 & 634,4 & 620,5 & 671,3 & 681,0 & 114,1 \\
\hline у т.ч. продукція тваринництва & млрд. грн. & 143,8 & 140,0 & 140,3 & 142,0 & 142,3 & 99,0 \\
\hline $\begin{array}{l}\text { Товарна структура експорту: } \\
\text { готові харчові продукти }\end{array}$ & $\%$ & 16,9 & 16,0 & 15,9 & 16,2 & 14,5 & 85,8 \\
\hline $\begin{array}{l}\text { жири й олії рослинного } \mathrm{i} \\
\text { тваринного походження }\end{array}$ & $\%$ & 22,7 & 25,9 & 25,9 & 24,2 & 21,4 & 94,3 \\
\hline $\begin{array}{lc}\text { сировинна } & \text { продукція } \\
\text { рослинництва і тваринництва }\end{array}$ & $\%$ & 60,4 & 58,1 & 58,2 & 59,6 & 64,1 & 106,1 \\
\hline
\end{tabular}

Джерело: за даними Державної служби статистики України

Разом із тим держава зобов'язана регулювати тільки ті норми, які $\epsilon$ обов'язковими, а виробників відповідно до цього необхідно мотивувати, озброювати новими сучасними знаннями i практичними науковими рекомендаціями, зокрема в питаннях запровадження сучасного менеджменту, ділової досконалості на мікро- і макрорівнях, розвитку самоврядування, що теж виступають важливими складовими сучасної системи державного управління $\mathrm{i}$ 
самоврядування аграрним сектором економіки та організації розвитку сільських територій.

Разом із тим розвиток аграрного сектору економіки України постійно зазнає впливу чисельних зовнішніх i внутрішніх чинників. На даному етапі перед органами державного управління виникають принципово нові, не менш важливі, складні та відповідальні завдання врегулювання масштабних процесів, які проявляються останнім часом в аграрній сфері та суттєво змінюють не тільки характер соціально-економічних та екологічних проблем, а й одночасно спричиняють появу нових, специфічних, у тому числі загрозливих тенденцій [10].

Участь України в міжнародних організаціях, необхідність виконання угоди про Свроасоціацію та інші обставини вимагають в аграрній сфері дотримання узгоджених ними принципів, критеріїв та відповідної ідентичності сталого розвитку, розширення інтеграційних процесів, що ще залишається важливим завданням політиків, законодавців, чиновників, органів самоврядування, вчених та безпосередньо учасників аграрного ринку. Дослідження вчених також показують, що в чистому вигляді при всіх відмінностях немає жодної країни 3 розвиненим агропромисловим виробництвом, де б цілком панувала ринкова стихія. Сучасна ринкова аграрна економіка у світі - це насамперед економіка регульованого i соціально орієнтованого господарства, де утверджується важлива роль держави у створенні сприятливих умов для ефективного функціонування аграрного ринку, гарантування належного рівня продовольчого забезпечення населення тощо. Вирішення таких завдань підтримується передусім збалансованими міжгалузевими відносинами, необхідним рівнем державної фінансової підтримки як виробників, так і споживачів продовольчих товарів, застосуванням різних механізмів податкового, кредитного, митного, інвестиційного, цінового, інноваційного та інших видів державного регулювання, страхуванням від природних і ринкових ризиків, які розробляють i реалізують в основному органи державного управління аграрним сектором економіки з широким залученням самоврядних організацій [8].

Як правило, у багатьох розвинених країнах такі механізми регулювання аграрного ринку стабільно діють протягом 5-7 років, а потім за необхідності переглядаються. Така практика державного регулювання, як одного з основних елементів державного управління, поряд із підприємливістю надає учасникам аграрного ринку впевненості в стабільності державної політики та прибутковості господарювання.

Для прикладу, стосовно державної бюджетної політики на відміну від такої практики, в Україні постійно змінюються механізми або взагалі скасовуються не лише окремі важливі бюджетні програми, а й обсяги державної підтримки в цілому. Протягом останніх років практично зникли такі напрями державної підтримки: обслуговуюча сільськогосподарська кооперація, дорадча діяльність, розвиток оптових продовольчих ринків, виконання цільових заходів із підвищення родючості грунтів, розвиток селекції в рослинництві і тваринництві, 
боротьба з шкідниками та хворобами рослин i тварин, організація виставок i біржової торгівлі, підтримка розвитку лізингу для придбання сільськогосподарської техніки і племінних тварин та багато інших, які не обмежуються правилами СОТ та не викривлюють цінову ситуацію на продовольчому ринку. А таким важливим цільовим програмам державної підтримки, як часткове здешевлення вартості кредитів, підтримка розвитку тваринництва, садівництва, виноградарства, ягідництва і хмелярства, малозабезпечених верств населення у придбанні продуктів харчування і цілому ряду інших притаманний нестабільний характер. Із метою наближення конкурентних переваг для вітчизняних сільгоспвиробників при вступі до СОТ Україна погодила, що обсяги їхньої державної підтримки можуть досягати до 3,4 млрд. дол. США (або майже 100 млрд. грн. за теперішнім курсом). Проте навіть орієнтовне наближення до таких обсягів підтримки жодного року не спостерігалося [11].

Висновки. Створення сприятливих умов для розвитку підприємництва $€$ одним із пріоритетних завдань державної політики. Важливо розробити та застосувати прямі і непрямі методи підтримки та заохочення підприємництва із соціально важливими якостями. Ключовим моментом забезпечення сталого розвитку підприємства на рівні держави $\epsilon$ заходи щодо регулювання податкового законодавства, створення ефективної системи фінансової підтримки, зміцнення виробничого потенціалу промислових підприємств шляхом виділення на пільгових умовах виробничих приміщень, техніки, сприяння підготовці кадрів та розвиток інноваційного підприємництва у науково-технічній сфері, створення інфраструктури.

\section{Лimepamypa:}

1. Гелбрейт Дж. К. Чому правий неправильний. The Guardian, 26 січня 1990, c. 3.

2. Global Economic Prospects. June 2021 / World Bank Group. - $172+$ xx pp. - P. xvii-xviii, 65-71. Режим доступу: https:// openknowledge.worldbank.org/bitstream/handle/10986/356471978 1464816659.pdf

3. Гриценко А.А. Методологія дослідження трансформації економічних функцій держави в умовах глобалізації. Економіка України. 2021. №7. С.5-13. Режим доступу: https://doi.org/10.15407/economyukr.2021.07.005

4. Гриценко А. Модернізація політико-економічних функцій держави // Соціологія і суспільство: взаємодія в умовах кризи. Харків, Харківський національний університет імені В. Н. Каразіна, 2013. С. 487-490.

5. Кіндзерський Ю. Інклюзивна індустріалізація для сталого розвитку: до принципів теорії та політики формування. Економіка України. 2021. №5. С.3-39. Режим доступу: doi.org/10.15407/economyukr.2021.05.003

6. Гриценко А., Борзенко (Сльозко) О., Бурлай Т. Європейська інтеграція України та ії сучасні виклики. 15-а Міжнародна наукова конференція професора Владаса Гронскаса Каунас (факультет Каунаса Вільнюського університету, 03 грудня 2020 р.), Відкрита серія Вільнюського університету, червень 2021 р., с. 6-11. Режим доступу: doi.org/10.15388/VGISC.2021.1

7. Взаємодоповнення інформаційно-цифрових та соціально-економічних перетворень як умова стабільного розвитку суспільства. А.А. Гриценко (Ред.). Київ, Інститут економіки та прогнозування НАН України, 2021. 
8. Гайдуцький П. І. Аграрна реформа Л.Д. Кучми в Україні. Київ: ТОВ «Інформаційні системи, 2015. 448 с.

9. Гладій М.В., Лузан Ю.Я. Аграрні трансформації та селянські господарства в системі продовольчої безпеки України. Економіка АПК. 2020. № 5. С. 6-21.

10. Андрійчук В.Г., Зубець М.В., Юрчишин В.В. Сучасна аграрна політика: проблемні аспекти. Київ: Аграрна наука, 2005. 14 с.

11. Державна служба статистики України. Режим доступу: http://www.ukrstat.gov.ua/.

\section{References:} Guardian. P.3.

1. Gelbreit, Dzh. K. (1990) Chomu pravyi nepravylnyi. [Why the right is wrong]. The

2. Global Economic Prospects (2021) World Bank Group. $172+$ xkh rr. P. xvii-xviii. pp.65-71. Retrieved from: https:// openknowledge.worldbank.org/bitstream/handle/10986/35647197814648 16659.pdf

3. Hrytsenko, A.A. (2021) Metodolohiia doslidzhennia transformatsii ekonomichnykh funktsii derzhavy v umovakh hlobalizatsii [Methodology of research of transformation of economic functions of the state in the conditions of globalization]. Ekonomika Ukrainy [Ukraine economy]. Vol.7. P.5-13. Retrieved from: https://doi.org/10.15407/economyukr.2021.07.005

4. Hrytsenko, A. (2013) Modernizatsiia polityko-ekonomichnykh funktsii derzhavy [Modernization of political and economic functions of the state] Sotsiolohiia $i$ suspilstvo: vzaiemodiia $v$ umovakh kryzy [Sociology and society: interaction in a crisis]. Kharkiv, Kharkivskyi natsionalnyi universytet imeni V.N. Karazina. P. 487-490 [in Ukrainian].

5. Kindzerskyi, Yu. (2021) Inkliuzyvna industrializatsiia dlia staloho rozvytku: do pryntsypiv teorii ta polityky formuvannia [Inclusive industrialization for sustainable development: the principles of theory and policy of formation.]. Ekonomika Ukrainy [Ukraine economy]. Vol. 5. P. 3-39. Retrieved from: doi.org/10.15407/economyukr.2021.05.003

6. Hrytsenko. A., Borzenko (Slozko). O., Burlai. T. (2021) Yevropeiska intehratsiia Ukrainy ta yii suchasni vyklyky [European integration of Ukraine and its current challenges]. 15- $a$ Mizhnarodna naukova konferentsiia profesora Vladasa Hronskasa Kaunas (fakultet Kaunasa Vilniuskoho universytetu, 03 hrudnia 2020) [15th International Scientific Conference of Professor Vladas Gronskas Kaunas (Kaunas Faculty, Vilnius University, December 3, 2020)], Vidkryta seriia Vilniuskoho universytetu, cherven 2021 [Vilnius University Open Series, June 2021], p. 6-11. Retrieved from: doi.org/10.15388/VGISC.2021.1

7. Vzaiemodopovnennia informatsiino-tsyfrovykh ta sotsialno-ekonomichnykh peretvoren yak umova stabilnoho rozvytku suspilstva [Complementarity of information-digital and socioeconomic transformations as a condition for stable development of society]. A.A.Hrytsenko (Red.). Kyiv, Instytut ekonomiky ta prohnozuvannia NAN Ukrainy, 2021. [in Ukrainian].

8. Haidutskyi, P.I. (2015) Ahrarna reforma L.D Kuchmy v Ukraini [Agrarian reform of LD Kuchma in Ukraine.]. Kyiv: TOV «Informatsiini systemy», 448 p. [in Ukrainian].

9. Hladii, M.V., Luzan, Yu.Ya. (2020) Ahrarni transformatsii ta selianski hospodarstva v systemi prodovolchoi bezpeky Ukrainy [Agrarian transformations and peasant farms in the food security system of Ukraine]. Ekonomika APK [Economics of agro-industrial complex]. Vol. 5. P. 6-21.

10. Andriichuk, V.H., Zubets M.V., Yurchyshyn V.V. (2005) Suchasna ahrarna polityka: problemni aspekty [Modern agricultural policy: problematic aspects.]. Kyiv: Ahrarna nauka, 14 p. [in Ukrainian].

11. Derzhavna sluzhba statystyky Ukrainy [State Statistics Service of Ukraine]. Retrieved from: http://www.ukrstat.gov.ua/. 